\title{
Local control of human papillomavirus infection after anal condylomata acuminata eradication
}

\section{Controle local da infecção perianal pelo papilomavirus humano após a erradicação dos condilomas acuminados}

Thiago da Silveira Manzione, TCBC'; Sidney Roberto Nadal, TCBC²; Edenilson Eduardo Calore ${ }^{3}$; Luís Roberto Manzione Nadal; ; Carmen Ruth Manzione, TCBC ${ }^{3}$

\section{A}

\begin{abstract}
Objective: To verify whether the eradication of anal condylomata acuminata was effective for local control of HPV infection using anal colposcopy and anal brush cytology. Methods: We evaluated 147 patients treated for anal margin and/or anal canal condyloma, with 108 HIV-positive and 39 HIV-negative individuals. The average age for males was 40 years for HIV-positive and 27.5 for HIVnegative. In females, the mean age was 37.5 years for HIV-positive and 31.5 for HIV-negative. Results: Twenty-four patients (16.3\%) had normal cytology and anal colposcopy, 16 (10.9\%) normal cytology and altered anal colposcopy, 52 (35.4\%) normal anal colposcopy and altered cytology, and 55 (37.4\%) had altered cytology and anal colposcopy. Conclusion: the eradication of clinical lesions failed to locally control HPV infection.
\end{abstract}

Key words: Mass screening. Papillomavirus infections. Neoplasms. Anal canal. Cell biology.

\section{INTRODUCTION}

T he human papillomavirus (HPV) is the most common among the various sexually transmitted etiological agents that cause disease in the anogenital region '. For Brazil, the World Health Organization (WHO) estimates the appearance of 684,400 new cases annually ${ }^{2}$. Its incidence has been increasing in recent years, associated with acquired immunodeficiency syndrome (AIDS) ${ }^{3}$, being / diagnosed between $15.7 \%$ and $62 \%$ of patients in different series ${ }^{1}$. It mainly affects men who have sex with men (MSM) ${ }^{1.3}$.

To date, more than 200 HPV types have been identified; 45 of them infect the anogenital region ${ }^{4}$. Oncogenic types are strongly related to the etiology of tumors of the anogenital tract and its precursor lesions ${ }^{5}$ and can be isolated in approximately $80-93 \%$ of anal carcinomas, the type 16 being the most frequent ${ }^{6,7}$.

Most HPV infections have no clinical consequence. However, $10 \%$ of patients will develop warts, papillomas or dysplasias ${ }^{8}$. It is believed that this fact depends on the level of individual virus resistance, systemic immunity and local factors, including local immunity ${ }^{8}$. The condition is not unique to immunocompromised individuals, but is most common when the serum T CD4 + lymphocyte count is below $500 / \mathrm{LL}^{9}$. The exclusively anal location is typical of
MSM due to the use of the anorectal segment to provide erotic pleasure ${ }^{10}$.

The difficulty of treatment, the high incidence of recurrence and the possibility of carcinomatous transformation, especially among the immunocompromised, are features of HPV. By reviewing the literature, we found recurrence rates between 10 and $88 \%$, depending on treatment 10,11 . It is difficult to differentiate cases of reinfection, though. There are those who associated relapses to the presence of latent infection in apparently normal epithelium ${ }^{12}$. Hence the importance of long-term followup and implementation of protocols to control the disease.

The possibility of detection of remaining or recurrent lesions, as well as the precursors of anal carcinoma, suggests that there should be instituted standardized screening and follow-up programs to prevent infection and decrease recurrence by HPV in patients at risk.

The cytology of the anal canal with brush has been performed ${ }^{13-16}$ with similar efficacy to the cervix collection ${ }^{17}$, and has a sensitivity ranging between 42 and $98 \%$ and specificity ranging from 38 to $96 \%$, when results were compared with histology $13,17,18$. Many authors recommend it as a method for screening populations at high risk for anal carcinoma ${ }^{19-21}$.

The anal colposcopy, having been recently introduced in the diagnostic arsenal for the specialty, is yet

1. Coloproctology, Faculty of Medical Sciences, São Paulo Holy Home (FCMSCSP); 2. Proctology Technical Staff, Emilio Ribas Institute of Infectious Diseases - IIER; 3. Pathology Technical Staff, IIER; 4. General Surgery Technical Staff, IIER. 
to have its indications well defined. Most Physicians carry it out as a screening method to identify the most appropriate sites for biopsy when after altered cytology. It has also been suggested for screening of precancerous lesions due to costeffectiveness in risk groups, amongst those the immunosuppressed ${ }^{20,21}$.

To date, the literature has not provided enough evidence for anal colposcopy and anal brush cytology to be used as forms of follow-up of treated patients to detect subclinical remaining lesions. Moreover, one cannot assess whether the treatment of condylomata acuminata was enough to eradicate HPV infection, preventing relapses and progression to carcinoma. Thus, we decided to check whether the eradication of anal condylomata acuminata is effective in local control of HPV infection using anal colposcopy and anal canal brush.

\section{METHODS}

We retrospectively analyzed data from patients seronegative and seropositive for HIV attended in the outpatient clinics after eradication of anal lesions caused by HPV. The visits occurred between March 2009 and October 2011 at the clinic of Proctology of the Emilio Ribas Institute of Infectious Diseases.

This study was approved by the Ethics in Research Committee of the Emilio Ribas Institute of Infectious Diseases under number 428/2009.

The sample consisted of 147 patients treated for condylomata acuminata of the anal margin and/or the anal canal. A hundred and eight were HIV seropositive, with 101 men and seven women, and 39 seronegative, 19 men and 20 women. The mean ages were 40 years for HIVpositive men and 27.5 years for HIV-negative. Among women, 37.5 years for HIV-positive and 31.5 years for HIVnegative.

We chose to include patients over 18 years, who had no clinical lesions caused by HPV 30 days after its eradication, obtained with clinical treatment associated or not with surgery, and pathological diagnosis confirming the anal HPV infection. We excluded patients who had the material of anal canal brush cytology from the two samples classified as inadequate or insufficient by the pathologist, and those with clinical recurrent or persistent lesions of the anal margin or anal canal.

Warts were diagnosed clinically with proctologic exam, which consisted of static and dynamic inspection, perianal palpation, rectal examination and anal colposcopy. Digital rectal examination and anal colposcopy were not performed when the disease covered the anal margin, which could cause pain and bleeding. Tissue samples were collected and subjected to histological examination to confirm clinical diagnosis.

The clinical treatment consisted of weekly applications of an ointment of $25 \%$ podophyllin in petrolatum on lesions of the anal margin and $90 \%$ trichloroacetic acid on lesions above the dentate line. Patients were evaluated after four applications and those with lingering injuries were referred to operative treatment. The verrucous lesions were sectioned with scissors, close to the skin, and hemostasis of bleeding points was made by electrocoagulation. Very small lesions were treated by electrofulguration. Warts' specimens were then sent to pathological examination.

Patients who showed no signs of disease 30 days after the eradication of anal warts were selected for follow-up, which consisted of two samples of anal cytology with brush and anal colposcopy with 3\% acetic acid.

The findings of cytology were distributed in unsatisfactory or satisfactory and in this case, according to cellularity, following the classification of Bethesda ${ }^{22,23}$. We considered the result with the highest degree of dysplasia for definitive diagnosis, regardless of it being observed in the first or second sample.

The findings of the anal colposcopy were divided into negative, when there were no changes, and positive when there were white lesions in the anal margin and/or anal canal.

We submitted the results to statistical analysis with the non-parametric Mann-Whitney test and the parametric Student's t and chi square tests. We considered the tolerance $<5 \%$ for all statistical tests.

\section{RESULTS}

Statistical analysis using the chi-square test revealed more men in the HIV seropositive population and equal incidence of genders in the group of seronegative ( $p$ $<0.0001)$.

Statistical analysis using the Student t test showed that HIV-positive men were more advanced in age than HIV-negative ones ( $p=0.037)$. There was no significant age difference between the seropositive and seronegative women $(p=0.282)$, nor between seropositive $(p=0.559)$ and seronegative $(p=0.295)$ men and women.

The findings of the cytology of the anal canal are shown in table 1.

The findings of the anal colposcopy are shown in table 2 .

Patients evaluated were divided into four groups according to the findings of anal cytology and colposcopy (Table 3).

The group with unchanged anal colposcopy and normal cytology consisted of 24 patients, five women and 19 men, aged 19 to 54 years, with mean 36.7. They were 11 seronegatives and 13 seropositives, with CD4 counts ranging from 204 to $780 / \mathrm{mL}$.

The group with altered anal colposcopy and normal cytology consisted of 16 patients, three women and 
13 men, aged from 20 to 55 years, mean 35.6. Five were seronegative and 11 seropositive, with CD4 counts ranging between 300 and 938/mL.

The group with normal anal cytology and altered colposcopy consisted of 52 patients, 12 women and 40 men, aged between 16 and 64 years, mean 38.7. Sixteen were seronegative and 36 seropositive, with CD4 counts ranging from 88 to $1463 / \mathrm{mL}$.

The group with abnormal anal cytology and colposcopy was comprised of 55 patients, seven women and 48 men, aged between 18 and 60 years, mean 37.1. There were seven seronegatives and 48 seropositives, with CD4 counts ranging from 200 to $1058 / \mathrm{mL}$.

Comparison of mean serum counts of CD4 T lymphocytes of HIV-positive patients with and without subclinical lesions showed no statistical difference (Mann-Whitney test $-p=0.704$ ). The presence of subclinical lesions was not associated with scores above and below 500/mL in HIV-positive patients $(p=0.771)$.

Table 1 - Findings of the anal canal brush cytology during follow-up.

\begin{tabular}{lcc}
\hline Cytological findings & $\mathrm{n}^{\circ}$ & $\%$ \\
\hline Negative & 40 & 27,2 \\
LSIL & 65 & 44,2 \\
HSIL & 41 & 27,9 \\
ASCUS & 01 & 0,7 \\
Total & 147 & 100 \\
\hline
\end{tabular}

LSIL - low grade squamous intraepithelial lesions

HSIL - high-grade squamous intraepithelial lesions of

ASCUS - atypical squamous cells of undetermined significance

Table 2 - Anal colposcopy findings during follow-up.

\begin{tabular}{lcc}
\hline Anal Colposcopy findings & $\mathbf{n}^{\circ}$ & $\%$ \\
\hline Negative & 76 & 51,7 \\
Injury in AC & 30 & 20,4 \\
Injury in AM & 22 & 15 \\
Injury in AC and AM & 19 & 12,9 \\
Total & 147 & 100 \\
\hline
\end{tabular}

AC- anal canal

$A M-$ anal margin

\section{DISCUSSION}

Our study evaluated more HIV-positive men than women, and similar numbers regarding gender among seronegatives. These data were expected because the number of men with HIV is four times higher than women in our country?

Regarding age, we observed that the group of seronegative men was the youngest. As we know that infection among men tends to maintain over time, and that it is more present in women up to 30 years of age ${ }^{24}$, we expected that the group of seronegative women to be the youngest. We suspect that the small number of women in the sample is responsible for this observation. On the other hand, among seropositive individuals the average age of men and women was similar, probably because the immunosuppression caused by HIV contributed to perpetuate HPV infection.

Although many authors recommend anal colposcopy and cytology as screening methods ${ }^{13-19,25}$, we have used the association of both methods to follow-up after treatment of anal HPV-induced lesions ${ }^{26}$. There is no universally accepted protocol that defines the period to perform anal colposcopy and cytology of the anal canal after eradication of warts. We indicated the exams 30 days after the end of treatment, when we observed no visible disease, a time sufficient to healing of wounds, preventing them from being confused with those of viral origin ${ }^{26}$. We also wanted to reduce discomfort during the exam, associated to the fact that during this period the patient would unlikely be reinfected, since he/she would be in convalescence. If the examination is normal, we recommend semiannual reassessments until three of them are normal. Some authors cite intervals of three ${ }^{27}$ and six months ${ }^{28}$ in the first year for follow-up and even annual screening tests ${ }^{29}$.

The present series allowed to define the period of one month as sufficient for the detection of subclinical lesions after eradication of warts. However, we believe that the expansion of the series will give strength to the evidence of current results.

In a previous study, when comparing the results of the cytology of the anal canal with one and two samples, we noted that the sensitivity with two samples was higher than the single collection and the specificity was similar 26 . For this reason, we adopted the two collections as a routine.

Table 3 - Distribution of the results of anal colposcopy and of the anal canal brush cytology during follow-up.

\begin{tabular}{lcccc}
\hline & Normal colposcopy & Altered colposcopy \\
\hline Normal cytology & 24 & $(16,3 \%)$ & 16 & $(10,9 \%)$ \\
Altered cytology & 52 & $(35,4 \%)$ & 55 & $(37,4 \%)$ \\
\hline
\end{tabular}


In our study, anal colposcopy showed HPVinduced lesions in the anal canal and anal margin in 48.3\% of patients examined. In other $35.4 \%$, the colposcope examination was normal, although cytology was altered. These facts showed that HPV infection was not completely controlled in $83.7 \%$ of patients. We found no published work with which we can compare these results. We also seek to assess whether HIV infection determines more relapse or more remaining lesions. But the small number of HIV-negative patients in the sample prevented this analysis.

When the condition is detected, treatment is initiated for controlling clinical relapses and preventing progression to malignancy. However, when the disease is evidenced only by cytology, it becomes impossible to define a therapy, because we do not know where the injuries are and we do not considered correct the application of topical agents on, or surgical resection of, random areas. Additionally, there may be false-positive results, as proven by an earlier study ${ }^{30}$. Anyway, we understand that the anal canal can be a reservoir of infection, and that at an appropriate time, usually when immunity falls, the diseases caused by this virus may reappear. Moreover, the colposcope is unable to visualize the interior of the crypts. If there is remaining infection in this location, it will not be detected by this method. However, cells with pattern of squamous intraepitelilal lesions (SIL) that have been detached can be captured by the brush, altering the result of cytology. For these reasons, we chose the combination of cytology and colposcopy examination with acetic acid and suggest that these methods should not be used alone in follow-up.

Recurrences are more frequent among those with lower CD4 + T lymphocytes ${ }^{29}$. In the present study, the seropositive patients had more subclinical lesions at followup. However, the comparison of mean serum counts of CD4 $+{ }^{29} \mathrm{~T}$ lymphocytes in HIV-positive patients with and without subclinical lesions showed no difference, and the presence of subclinical lesions was not associated with scores above and below 500/mL, showing that immunity did not influence this effect.

We intend to continue this study by assessing whether the presence of oncogenic HPV types would increase the rate of recurrent or remaining subclinical lesions in the treated patients. We are also concerned about the outcome of patients with normal anal colposcopy and abnormal anal brush cytology, for whom we are developing further study.

The results obtained in the present study, in which we perform anal brush cytology and anal colposcopy for follow-up of patients treated for anal condylomata acuminata, showed that eradication of clinical lesions did not locally control the infection with human papillomavirus and that periodic control should be instituted.

\title{
RE S U M O
}

\begin{abstract}
Objetivo: verificar se a erradicação dos condilomas acuminados perianais foi efetiva no controle local da infecção pelo HPV, utilizando a colposcopia anal e a citologia anal com escova. Métodos: avaliamos 147 pacientes tratados de condiloma da margem e/ou canal anal, sendo 108 HIV-positivos e 39 HIV-negativos. A média etária no sexo masculino foi 40 anos para os HIV-positivos e 27,5 anos para os HIV-negativos. No sexo feminino, a média etária foi 37,5 anos para os HIV positivos e 31,5 anos HIV-negativos. Resultados: vinte e quatro pacientes (16,3\%) apresentavam citologia e colposcopia normais, 16 (10,9\%) citologia normal e colposcopia alterada, 52 (35,4\%) citologia alterada e colposcopia normal e 55 (37,4\%) citologia e colposcopia alteradas. Conclusão: a erradicação das lesões clínicas não controlou localmente a infecção pelo HPV.
\end{abstract}

Descritores: Programas de rastreamento. Infeç̧ões por papillomavirus. Neoplasias. Canal anal. Biologia celular.

\section{REFERENCES}

1. Nadal SR, Manzione CR, Horta SHC. Comparison of perianal diseases in HIV-positive patients in periods before and after HAART use. Dis Colon Rectum. 2008;51(10):1491-4.

2. Departamento de DST, AIDS e Hepatites Virais. Ministério da Saúde. DST no Brasil, 2012. Disponível em: portal.saude.gov.br/portal/ arquivos/pdf/gerson_pereira.pdf

3. van der Snoek EM, van der Ende ME, den Hollander JC, Schutten $M$, Neumann HA, van Doornum GJ. Use of highly active antiretroviral therapy is associated with lower prevalence of anal intraepithelial neoplastic lesions and lower prevalence of human papillomavirus in HIV-infected men who have sex with men. Sex Transm Dis. 2012;39(7):495-500.

4. Banura C, Mirembe FM, Katahoire AR, Namujju PB, Mbonye AK, Wabwire FM. Epidemiology of HPV genotypes in Uganda and the role of the current preventive vaccines: a systematic review. Infect Agent Cancer. 2011;6(1):11

5. Carvalho MO, Carestiato FN, Perdigao PH, Xavier MP, Silva K, Botelho MO, et al. Human papillomavirus infection in Rio de Janeiro, Brazil: a retrospective study. Braz J Infect Dis. 2005;9(5):398404.

6. Dunne EF, Nielson CM, Stone KM, Markowitz LE, Giuliano AR. Prevalence of HPV infection among men: a systematic review of the literature. J Infect Dis. 2006;194(8):1044-57.

7. Giuliano AR, Tortolero-Luna G, Ferrer E, Burchell AN, de Sanjose $S$, Kjaer SK, et al. Epidemiology of human papillomavirus infection in men, cancers other than cervical and benign conditions. Vaccine. 2008;26 (Suppl 10):K17-28.

8. Nadal SR, Manzione CR. Vacina contra o Papilomavirus Humano. O que é preciso saber? Rev bras colo-proctol. 2010;30(2): 237-40. 
9. Nadal SR, Calore EE, Manzione TS, Machado SP, Manzione CR, Seid VE, et al. Evolução dos doentes com citologia oncótica alterada e colposcopia anal normal. Rev bras colo-proctol. 2011;31(1):71 6.

10. Manzione CR, Nadal SR, Calore EE. Postoperative follow-up of anal condylomata acuminata in HIV-positive patients. Dis Colon Rectum. 2003:46(10):1358-65.

11. D'Ambrogio A, Yerly $S$, Sahli $R$, Bouzourene $H$, Demartines $N$ Cotton $\mathrm{M}$, et al. Human papilloma virus type and recurrence rate after surgical clearance of anal condylomata acuminata. Sex Transm Dis. 2009;36(9):536-40.

12. Kreuter A, Brockmeyer NH, Hochdorfer B, Weissenborn SJ, Stucker $M$, Swoboda J, et al. Clinical spectrum and virologic characteristics of anal intraepithelial neoplasia in HIV infection. J Am Acad Dermatol. 2005;52(4):603-8.

13. Friedlander MA, Stier $E$, Lin O. Anorectal cytology as a screening tool for anal squamous lesions: cytologic, anoscopic, and histologic correlation. Cancer. 2004;102(1):19-26.

14. Arain $S$, Walts $A E$, Thomas $P$, Bose $S$. The anal pap smear: cytomorphology of squamous intraepithelial lesions. Cytojournal. 2005;2(1):4

15. Piketty C, Darragh TM, Da Costa M, Bruneval P, Heard I, Kazatchkine MD, et al. High prevalence of anal human papillomavirus infection and anal cancer precursors among HIVinfected persons in the absence of anal intercourse. Ann Intern Med. 2003;138(3):453-9.

16. Fox PA, Seet JE, Stebbing J, Francis N, Barton SE, Strauss $S$, et al. The value of anal cytology and human papillomavirus typing in the detection of anal intraepithelial neoplasia: a review of cases from an anoscopy clinic. Sex Transm Infect. 2005;81(2):142-6.

17. Papaconstantinou HT, Lee AJ, Simmang CL, Ashfaq R, Gokaslan ST, Sokol S, et al. Screening methods for high-grade dysplasia in patients with anal condyloma. J Surg Res. 2005;127(1):8-13.

18. Vajdic CM, Anderson JS, Hillman RJ, Medley G, Grulich AE. Blind sampling is superior to anoscope guided sampling for screening for anal intraepithelial neoplasia. Sex Transm Infect. 2005;81(5):4158.

19. Giuliano AR, Nielson CM, Flores R, Dune EF, Abrahamsen M, Papenfuss MR, et al. The optimal anatomic sites for sampling heterossexual men for human papillomavirus (HPV) detection: the HPV detection in men study. J Infect Dis. 2007;196(8):1146-52.

20. Nadal SR, Manzione CR. Manejo das neoplasias intra-epiteliais anais. Rev bras colo-proctol. 2008;28(4):462-4.

21. Park IU, Palefsky JM. Evaluation and management of anal intraepithelial neoplasia in HIV-negative and HIV-positive men who have sex with men. Curr Infect Dis Rep. 2010;12(2):126-33.
22. Bethesda System 2001 Terminology [homepage on the internet]. Bethesda (MD): National Cancer Institute; [cited 2005 Sep 29]. Available from: http://bethesda2001.cancer.gov/terminology.html

23. Nomenclatura Brasileira para laudos cervicais e condutas preconizadas: recomendações para profissionais de saúde. Rev Bras Ginecol Obstet. 2006;28(8):486-504

24. Dietz CA, Nyberg CR. Genital, oral, and anal human papillomavirus infection in men who have sex with men. J Am Osteopath Assoc. 2011;111(3 Suppl 2):S19-25.

25. Mathews WC. Screening for anal dysplasia associated with human papillomavirus. Top HIV Med. 2003:11(2):45-9.

26. Nadal SR, Calore EE, Manzione CR, Arruda CN, Cha JD, Formiga $\mathrm{FB}$, et al. Sensibilidade e especificidade da citologia anal com escova no diagnóstico das lesões clínicas provocadas pelo papilomavírus humano, comparando uma com duas coletas. Rev bras colo-proctol. 2009;29(3):297-302.

27. Herat A, Whitfeld M, Hillman R. Anal intraepithelial neoplasia and anal cancer in dermatological practice. Australas J Dermatol. 2007;48(3):143-53

28. Chang GJ, Berry JM, Jay N, Palefsky JM, Welton ML. Surgical treatment of high-grade anal squamous intraepithelial lesions: a prospective study. Dis Colon Rectum. 2002;45(2):453-8.

29. Lehtovirta P, Paavonen J, Heikinheimo O. Risk factors, diagnosis and prognosis of cervical intraepithelial neoplasia among HIVinfected women. Int J STD AIDS. 2008;19(1):37-41.

30. Nadal SR, Calore EE, Nadal LRM, Horta SHC, Manzione CR. Citologia anal para rastreamento de lesões pré-neoplásicas. Rev Assoc Med Bras. 2007;53(2):147-151.

Received on 10/12/2012

Accepted for publication 15/02/2013

Conflict of interest: none.

Source of funding: none.

\section{How to cite this article:}

Manzione TS, Nadal SR, Calore EE, Nadal LRM, Manzione CR. Local control of perianal human papillomavirus infection after eradication of condylomata acuminata. Rev Col Bras Cir. [periódico na Internet] 2014;41(2). Disponível em URL: http://www.scielo.br/rcbc

\section{Address for correspondence:}

Sidney Roberto Nadal

E-mail: srnadal@terra.com.br 